\section{Christina Mallarino'}

Luis F Gómez'

Laura González-Zapata"

Yazmín Cadena'

Diana C Parra"II

\section{Advertising of ultra-processed foods and beverages: children as a vulnerable population}

\section{Publicidade de bebidas e alimentos ultra-processados: crianças como população vulnerável}

\begin{abstract}
The rapid nutrition transition occurring in Latin America has resulted in a sharp increase of childhood overweight and obesity. Recent evidence has shown that food and beverage advertising has a great influence on children's eating behavior. This population has become a key target market for the ultra-processed foods and beverages industry, which is marketing products in an aggressive way. Evidence shows that Latin American countries have poor regulation of ultra-processed foods and beverages advertising, where the discourse of self-regulation still prevails over statutory regulations. The following commentary explores how advertising might play an important role in developing unhealthy dietary patterns and obesity in Latin American children, as well as the urgent need for government action and the involvement of civil society to tackle this public health issue.
\end{abstract}

DESCRIPTORS: Child. Food Publicity. Industrialized Foods. FoodProcessing Industry. Nutritional Transition.

\section{RESUMO}

A rápida transição nutricional na América Latina tem como resultado o aumento pronunciado de sobrepeso e obesidade nas crianças. Evidência recente mostra que a publicidade de comidas e bebidas tem grande influência nas preferências alimentares das crianças. Essa população torna-se alvo da indústria de alimentos ultraprocessados e bebidas, produtos comercializados agressivamente. Nos países da América Latina, só existem regulamentos ineficientes para a publicidade de bebidas e alimentos ultraprocessados, e o discurso de auto-regulação prevalece sobre os regulamentos legais. Este comentário explora o papel importante da publicidade no desenvolvimento de padrões de dietas não saudáveis e na obesidade das crianças na América Latina, bem como a necessidade de ação governamental e participação social na resolução desse problema de saúde pública.

DESCRITORES: Criança. Publicidade de Alimentos. Alimentos Industrializados. Indústria de Processamento de Alimentos. Transição Nutricional. 


\section{INTRODUCTION}

"He (Ronald McDonald) does not advertise unhealthy food to children. We provide many choices that fit with the balanced, active lifestyle. It is up to them to choose and their parents to choose, and it is their responsibility to do so." - Jim Skinner, McDonald's CEO ${ }^{a}$

Many people would agree with Skinner in that it is the parents' responsibility to choose what their children are eating. This might appear to be right, since they are the ones who buy food for their children and should have the authority to control their dietary habits. However, if this was entirely true, would food and beverage companies be spending so much money, time, and effort on advertising to children? In the United States, the food and beverage industry invests more than 10 billion dollars/year in marketing to children, using sophisticated methods to compile a detailed profile of its target consumers. ${ }^{9}$ There is growing evidence that television advertising influences the food preferences of children. ${ }^{9}$ These young consumers are making choices in the marketplace at younger ages either by influencing the food selections of parents and caregivers or by making purchasing decisions independent of parental guidance. ${ }^{9}$ As part of the rapid nutrition transition occurring in Latin America, childhood obesity is rising at an alarming rate. This increase is intimately related to the accelerated globalization process occurring in highly urbanized areas, where a greater percentage of the population is now being exposed to the marketing of ultra-processed foods and beverages. ${ }^{5,6}$ This commentary explores how advertising might play an important role in developing unhealthy dietary patterns and obesity in Latin American children (defined as those below the age of 18). There is an urgent need for government action and the involvement of civil society in order to tackle this public health issue.

\section{Nutrition transition in Latin America}

The nutrition transition in Latin America has been characterized by the increasing consumption of energy-dense foods and beverages rich in refined sugars, salt, and fat, but poor in other essential nutrients. ${ }^{1,10,11}$ There has been a sharp increase in the rate of nutrition-related non-communicable diseases such as obesity, hypertension, and diabetes mellitus, for which children are no exception. ${ }^{2,15}$ In Latin America, dietary patterns have undergone profound changes in recent years. In Brazil, consumption of whole or minimally processed foods such as rice, beans, and eggs, has decreased between ten and 27 percent in 16 years. The intake of bread and biscuits increased by $21 \%$ during the same period, while consumption of meat products, dairy products, soft drinks and sweets increased by more than $100 \% .{ }^{11}$ In Mexico, the intake of fruit and vegetables decreased by $29.3 \%$ between 1984 and 1998, while the consumption of refined carbohydrates and soft drinks increased $6.3 \%$ and $37.2 \%$, respectively. ${ }^{14}$ Several national nutrition surveys conducted in the region show that childhood obesity is growing at a rapid pace. In Brazil, the proportion of overweight girls aged five to nine years old increased from $8.6 \%$ in 1975 to $32 \%$ in 2009 . The rates went from $10.9 \%$ to $34.8 \%$ in boys of the same age. ${ }^{b}$ The prevalence of overweight and obesity in Mexican children aged five to 11 increased from $18.6 \%$ in 1999 to $26.6 \%$ in $2006 .{ }^{\circ}$ Between 2005 and 2010, overweight and obesity in children aged 11 to 17 years old increased by $25.9 \%$ in Colombia. ${ }^{\mathrm{d}}$

\section{ADVERTISING UNHEALTHY FOOD AND BEVERAGES TO CHILDREN: IS THE INDUSTRY TAKING ADVANTAGE?}

Although there are several factors linked with dietary behaviors, including biological and genetic characteristics, as well as school and family environments, the marketing strategies used by the ultra-processed food and beverage industry is one of the main drivers that might explain these dietary changes. A recent systematic review showed strong evidence that television advertising influences the food and beverage preferences of children aged two to 11 years old. ${ }^{9}$ Another review found a significant association between the number of food advertisements that are shown per hour during children's programming and the proportion of overweight children in the USA, Australia, and eight European countries. ${ }^{9}$

The massive television food advertisement in Latin America is exemplified in the study conducted in 2010 by the independent Mexican organization El Poder del Consumidor (The Power of the Consumer). This study registered the amount of junk food television commercials that were aired during children's programming. The

\footnotetext{
a McDonald's CEO on Ronald: "This is about choice". Dairy Herald [updated 2011 Nov 5]. [cited 2013 Oct 6]. Available from: http://www. dailyherald.com/article/20110519/news/705199917/print/

b Instituto Brasileiro de Geografia e Estatística. POF 2008-2009: desnutrição cai e peso das crianças brasileiras ultrapassa padrão internacional. Rio de Janeiro; 2013 [cited 2013 Mar 18]. Available from: http://www.ibge.gov.br/home/presidencia/noticias/noticia_visualiza. php?id_noticia=1699\&id_pagina=1

c Instituto Nacional de Salud Pública de México. Encuesta nacional de salud y nutrición 2006. Cuernavaca; 2007 [cited 2013 Oct 7]. Available from: : http://www.insp.mx/images/stories/Produccion/pdf/100722_cp3.pdf]

d Instituto Colombiano de Bienestar Familiar Cecilia De La Fuente de Lleras. Encuesta Nacional de la Situación Nutricional en Colombia 2010 - ENSIN 2010. Bogotá; 2010 [cited 2011 Oct 10]. Available from: http://www.icbf.gov.co/portal/page/portal/PortalICBF/NormatividadGestion/ ENSIN1
} 
average number of ads was 11.5/hour, with Kellogg's, Nestlé, and Bimbo products accounting for $58 \%$ of the entire advertising. ${ }^{\mathrm{e}}$ In 2008, the Mexican Department of Health found that $41 \%$ of commercials aired during children's programming promoted ultra-processed foods and beverages, mainly bread and snack cakes (39.3\%). ${ }^{\text {f }}$ This study estimated that Mexican children are exposed to 343 food and beverage commercials per week. This has an important impact, since $94.7 \%$ of homes in Mexico have a television set and this is only one of the many media outlets used for advertising. ${ }^{\mathrm{g}}$ The industry is now implementing alternative strategies to advertise its products to children, such as web pages, social networks, advergames, and mobile phones. ${ }^{9}$ The investment in interactive advertising has increased in the past years and it is projected to rise substantially in the future. ${ }^{12}$ These strategies allow companies to create personalized marketing based on the sites that consumers visit and the products they buy online. People become active actors in advertising by engaging in advergames, sharing links through social networks, voting for a certain product online or through SMS, and even participating in the design of certain ads. ${ }^{12}$ Interactive media has given companies the power of building long-term and emotional relationships between consumers and brands. ${ }^{12}$ Furthermore, this type of media transcends geographic boundaries, since web pages may be viewed in most countries irrespective of the place where they are created. ${ }^{13}$ Examples of ultra-processed food companies that use these strategies in Latin America are Nestlé and D’Onofrio, among many others.

There are two main reasons why we should prioritize children when regulating food advertising. Firstly, this population is especially vulnerable to food and beverage advertising because they do not have the neurological maturity to understand the marketing intentions behind the ads, and to make autonomous decisions regarding a healthy diet. ${ }^{3,8}$ Several studies have found that abstract thinking, neurological maturity, and full capacity to make appropriate decisions are only accomplished after the age of $18 .^{3,8}$ Children have become an important target for the ultra-processed food and beverage companies that use aggressive advertising strategies to generate brand awareness, preference, and loyalty. ${ }^{9}$ Consequently, they end up being at greater risk of acquiring unhealthy dietary habits because of major exposure to advertising of foods with empty calories. Sweden and Norway are examples of countries that protect this population, precisely because children are trusting and unable to understand the differences between television commercials and programming. ${ }^{9}$ The second reason is that dietary habits are built early in life and usually persist through adulthood $;{ }^{9}$ if we protect children now and create a healthful food environment, we are also safeguarding future adults from obesity and other nutrition-related non-communicable diseases.

\section{STATUTORY VERSUS SELF-REGULATION: IS LATIN AMERICA AVOIDING EFFECTIVE ACTIONS?}

In 1992, the Norwegian broadcasting law banned any advertisement that promoted products "directed at children" and prohibited any commercial that was aimed at this population. ${ }^{9, j}$ Similarly, the Swedish Radio and Television Act forbade any advertising "designed to attract the attention of children younger than 12 years old". ${ }^{\mathrm{N}}$ In Latin America, there has been some progress towards the regulation of advertising to children. In Brazil, one regulation issued by the National Health Surveillance Agency (ANVISA), although still not enforced, requires health warnings in advertisements for foods with high amounts of sugar, saturated fat, trans fat and sodium, and for beverages with low nutritional value. ${ }^{1}$ The initial draft of this regulation was stricter, with complete prohibition of television promotion of these products between 6:00 a.m. and 9:00 p.m., among other restrictions. ${ }^{\mathrm{k}}$ In Chile, Congress approved a law that regulates food and beverage advertisement directed at children younger than 14 years of age. ${ }^{\mathrm{m}}$

\footnotetext{
e El Poder del Consumidor. México, líder en publicidad chatarra: Tigre Toño y Ronald Reagan ganan en engaño publicitario. México (DF); 2011 [cited 2013 Mar 20]. Available from: http://www.elpoderdelconsumidor.org/saludnutricional/mexico-lider-en-publicidad-chatarra/

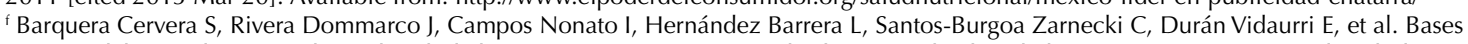
técnicas del acuerdo nacional para la salud alimentaria: estrategia contra el sobrepeso y la obesidad. México (DF): Secretaría de Salud; 2010 [cited 2013 Mar 15] Available from: http://www.promocion.salud.gob.mx/dgps/descargas1/programas/Bases_tecnicas_acuerdo_nacional_ obesidad_29_mar_10_completo.pdf

$\mathrm{g}$ Instituto Nacional de Estadística y Geografía. Estadísticas sobre disponibilidad y uso de tecnología de información y comunicaciones en los hogares, 2010. México (DF); 2011 [cited 2013 Mar 20]. Available from: http://www.inegi.org.mx/prod_serv/contenidos/espanol/bvinegi/ productos/encuestas/especiales/endutih/2010/ENDUTIH2010.pdf

${ }^{\mathrm{h}}$ Helados D'Onofrio, Perú. [cited 2013 Mar 15]. Available from: http://www.heladosdonofrio.com

i Nestlé Brazil. MaisDivertido. [cited 2013 Mar 20]. Available from: http://www.nestle.com.br/maisdivertido/

i Norway. Ministry of Culture. Act $n^{\circ} 127$ of 4 December 1992 relating to Broadcasting. [cited 2013 Mar 20]. Available from: http://www. regjeringen.no/en/dep/kkd/Documents/acts-and-regulations/reglement/2005/broadcasting-act-.html?id=420612

k Olsen L. Children and advertising: some perspectives on the relevant legal arguments. Stockholm: Stockholm Institute for Scandinavian Law;1957-2010 [cited 2013 mar 20]. Available from: http://www.scandinavianlaw.se/pdf/50-29.pdf

${ }^{\prime}$ Agência Nacional de Vigilância Sanitária. Resolução-RDC № 24, de 15 de junho de 2010. Dispõe sobre a oferta, propaganda, publicidade, informação e outras práticas correlatas cujo objetivo seja a divulgação e a promoção comercial de alimentos considerados com quantidades elevadas de açúcar, de gordura saturada, de gordura trans, de sódio, e de bebidas com baixo teor nutricional, nos termos desta Resolução, e dá outras providências. [cited 2013 Mar 20]. Available from: http://portal.anvisa.gov.br/wps/wcm/connect/34565380474597549fd4df3fbc 4c6735/RDC24_10_Publicidade+de+alimentos.pdf?MOD=AJPERES

m Senado de la República de Chile. Proyecto de Ley sobre regulación de alimentos poco saludables. [cited 2013 Mar 20]. Available from: http://www.guidogirardi.cl/proyectos-ciudadanos/proyecto-de-ley-alimentos-poco-saludables/
} 
Initially, President Piñera held a veto on the bill. Some argue that this was mainly due to lobbying from the Federation of Chilean Industry (SOFOFA). ${ }^{\mathrm{n}}$ The law finally took effect in July 2012, but there is still controversy surrounding the way it is being implemented. In Colombia, a law aimed at controlling obesity was approved in 2009, stating that the Ministry of Health and Social Protection, and the National Institute for Food and Medicine Surveillance (In Spanish: Instituto Nacional de Vigilancia de Medicamentos y Alimentos, INVIMA) are required to create a specialized committee that must control food and beverage advertising in order to protect the health of consumers, mainly children and adolescents. ${ }^{\circ}$ Nevertheless, these institutions have yet to create such committee.

Unfortunately, the self-regulatory discourse still prevails over statutory regulations in Latin America. Surprisingly, the country with the highest prevalence of childhood obesity in the region only has a self-regulatory commitment on food and beverage advertising, and it is in itself ambiguous. The Mexican Self-regulatory code for food and non-alcoholic beverages aimed at children (PABI - in Spanish: Código de Autoregulación de Publicidad de Alimentos y Bebidas No Alcohólicas dirigida al Público Infantil) uses nonspecific terms such as "avoid the use" or "risking or hurting their (children's) physical or mental health". ${ }^{\mathrm{p}}$ This code attributes a lot of responsibility to the parents, stating that publicity should "strengthen family and school relationships in a constructive manner, recognizing, at every moment, that parents and caregivers bear the main responsibility for health education and should guide their children". ${ }^{\circ}$ There has been much controversy within Mexican public opinion because this code does not include the main advertising strategies used by the industry, such as prizes and toys. ${ }^{\mathrm{q}}$ Additionally, the code has not been followed by many of the companies that signed the agreement and some argue that it was created to avoid legislation on this matter, since it was issued soon after the Health Department expressed the need for regulating food and beverage advertising directed at children. ${ }^{\mathrm{p}}$ Another example is the Colombian self-regulatory advertising code issued in 1998, where there is only one article that addresses this problem, stating that "the advertisement of products not comprising part of the basic diet, such as appetizers, desserts, sweets, chewing gum, and drinks made with artificial ingredients, must not suggest that these products can be substitutes for the basic diet". ${ }^{\mathrm{r}}$ The major difficulty of having self-regulatory commitments is that they are not legally binding and might divert governments from taking the most effective action, which is regulation. ${ }^{7,10}$ This is especially true for Latin America, where low civil society involvement and lack of government supervision are common.

\section{A CALL FOR ACTION}

In the early 1990s, there was less evidence of the neurological development of children and the effect that publicity has on their consumer behavior. Regardless of this, Norway and Sweden still issued laws that regulated advertisement directed at this population, out of common sense and respect for their vulnerability. Today, we have enough evidence on this matter and Latin America is still lacking effective efforts to tackle this problem through statutory regulations and active participation of civil society. Governments have the obligation to protect children's rights, which includes regulating factors that may harm their health, and clearly, aggressive marketing of ultra-processed food and beverage products is one of them. The bottom line is that decision-makers have two choices: they can either sit back and believe what the industry wants them to believe - that personal responsibility and choice are the only determinants of our eating behaviors - or they can face the evidence and understand that the food environment plays a greater role than we would like to admit, and take effective action to modify this obesogenic milieu.

\section{ACKNOWLEDGMENTS}

To Professor Carlos Monteiro from the Department of Nutrition, Faculdade de Saúde Pública of the Universidade de São Paulo, for his important guidance and critical review of the manuscript.

\footnotetext{
${ }^{n}$ Girardi G. Sofofa realiza intenso lobby contra proyecto que regula "comida chatarra", 2009. [cited 2013 Mar 20]. Available from: http:// guidogirardi.cl/?p=5442

${ }^{\circ}$ Congreso de la República de Colombia. Ley 1355 de 14 de octubre de 2009. Define la obesidad y las enfermedades crónicas no transmisibles asociadas a esta como una prioridad de salud pública y se adoptan medidas para su control, atención y prevención. [cited 2013 Mar 20]. Available from: http://www.secretariasenado.gov.co/senado/basedoc/ley/2009/ley_1355_2009.html

P Código de autorregulación de publicidad de alimentos y bebidas no alcohólicas dirigidas al público infantil. México (DF); 2009 [cited 2013 Mar 15]. Available from: http://www.e-consulta.com/blogs/educacion/imgs_10/codigo_pabi.pdf

${ }^{q}$ El código PABI se respeta? Rev Consumidor [Internet]. 2011 Apr 28 [cited 2013 Mar 20]. Available from: http://revistadelconsumidor.gob. $\mathrm{mx} / \mathrm{p}=17623$

r Comisión Nacional de Autorregulación Publicitaria - CONARP. Código colombiano de autorregulación publicitaria: artículo n 46 . Bogotá; 1998 [cited 2013 Mar 20]. Available from: http://www.slideshare.net/imaginead/cdigo-colombiano-de-autorregulacin-publicitaria
} 


\section{REFERENCES}

1. Barquera S, Campirano F, Bonvecchio A, HernándezBarrera L, Rivera JA, Popkin BM. Caloric beverage consumption patterns in Mexican children. Nutr J. 2010;9:47. DOI:10.1186/1475-2891-9-47

2. Cutler JA, Roccella EJ. Salt reduction for preventing hypertension and cardiovascular disease: a population approach should include children. Hypertension. 2006;48(5):818-9. DOI:10.1161/01.HYP.0000245673.93844.6d

3. Dosenbach NU, Nardos B, Cohen AL, Fair DA, Power JD, Church JA, et al. Prediction of individual brain maturity using fMRI. Science. 2010;329(5997):1358-61. DOI:10.1126/science.1194144

4. Freedman DS, Mei Z, Srinivasan SR, Berenson GS, Dietz $\mathrm{WH}$. Cardiovascular risk factors and excess adiposity among overweight children and adolescents: the Bogalusa Heart Study. J Pediatr. 2007;150(1):12-17.e2. DOI:10.1016/j.jpeds.2006.08.042

5. Garrett JL, Ruel MT. Stunted child-overweight mother pairs: prevalence and association with economic development and urbanization. Food Nutr Bull. 2005;26(2):209-21.

6. Gómez L, Jacoby E, Ibarra L, Lucumí D, Hernandez A, Parra D, et al. Sponsorship of physical activity programs by the sweetened beverages industry: public health or public relations? Rev Saude Publica. 2011;45(2):423-7. DOI:10.1590/S0034-89102011000200022

7. Hawkes C, Harris JL. An analysis of the content of food industry pledges on marketing to children. Public Health Nutr. 2011;14(8):1403-14. DOI:10.1017/S1368980011000607
8. Lobstein T, Dibb S. Evidence of a possible link between obesogenic food advertising and child overweight. Obes Rev. 2005;6(3):203-8. DOI:10.1111/j.1467-789X.2005.00191.x

9. McGinnis JM, Gootman JA, Kraak VI, editors. Food marketing to children and youth: threat or opportunity? Washington (DC): The National Academies Press; 2006.

10. Monteiro CA, Levy RB, Claro RM, Castro IR, Cannon G. Increasing consumption of ultra-processed foods and likely impact on human health: evidence from Brazil. Public Health Nutr. 2011;14(1):5-13. DOI:10.1017/S1368980010003241

11. Monteiro CA. The big issue is ultra-processing. In praise of the shared meal [editorial and commentary]. World Nutr. 2011;2(5):235-46

12. Montgomery KC, Chester J. Interactive food and beverage marketing: targeting adolescents in the digital age. J Adolesc Health. 2009;45(3 Suppl):S18-29. DOI:10.1016/j.jadohealth.2009.04.006

13. Lobstein T. Research needs on food marketing to children: report of the StanMark project. Appetite. 2013;62:185-6. DOI:10.1016/j.appet.2012.10.010

14. Rivera JA, Barquera S, Campirano F, Campos I, Safdie M, Tovar V. Epidemiological and nutritional transition in México: rapid increase of non-communicable chronic disease and obesity. Public Health Nutr. 2002;5(1A):113-22. DOI:10.1079/PHN2001282

15. Uscátegui Peñuela RM, Álvarez Uribe MC, Laguado Salinas L, Soler Terranova W, Martinez Maluendas L, Arias Arteaga $\mathrm{R}$, et al. Factores de riesgo cardiovascular en niños de 6 a 18 años de Medellín (Colombia). An Pediatr (Barc). 2003;58(5):411-7.

The authors declare that there are no conflicts of interest.

\section{CORRECTION}

\section{Affiliation for Christina Mallarino, Luis F Gómez and Yazmín Cadena}

Where it reads:

"Departamento de Medicina Preventiva y Social. Facultad de Medicina. Hospital Universitario San Ignacio. Medllin, Antioquia, Colombia"

It should read:

"Departamento de Medicina Preventiva y Social. Facultad de Medicina. Pontificia Universidad Javeriana. Bogotá, Colombia" 